\title{
INTERNALISASI NILAI-NILAI PANCASILA DALAM UPAYA MEMBENTUK PELAJAR ANTI NARKOBA
}

\author{
Nurhadianto, Prodi Pendidikan Kewarganegaraan SPs, Universitas Pendidikan Indonesia, \\ email: nadi.nurhadianto@gmail.com
}

\begin{abstract}
ABSTRAK
Pancasila merupakan ideologi negara yang telah disepakati sebagai dasar dalam penyelenggaraan kehidupan bermasyarakat, berbangsa, dan bernegara. Pengamalan nilainilai pancasila tentunya akan membawa pada perkembangan kehidupan masyarakat yang berketuhanan, berperi-kemanusiaan, bersatu, berkerakyatan, dan berkeadilan. Sebaliknya, lunturnya pengamalan nilai-nilai dasar tersebut akan menyebabkan berbagai tindakan disorder yang dapat menancam seluruh lini kehidupan. Salah satunya adalah penyalahgunaan narkoba di kalangan remaja. Sampai hari ini, penyalahgunaan narkoba di kalangan remaja masih menjadi ancaman besar bagi bangsa Indonesia. Tidak hanya merusak perkembangan mental secara pribadi, kondisi ini tentunya menyebabkan kerusakan jangka panjang bagi bangsa dan Negara Indonesia. Kelompok usia remaja merupakan social capital negara Indonesia. Apabila modal sosial ini sudah tidak mampu berbuat banyak karena pasungan dampak buruk narkoba tersebut, bagaimana mereka akan berpartisipasi dalam menunaikan janji kemerdekaan bangsa dan Negara Indonesia. Oleh sebab itu, internalisasi nilai-nilai pancasila di kalangan remaja dirasa sangat diperlukan agar sikap dan perilaku para remaja senantiasa dijiwai nilai-nilai luhur Pancasila.
\end{abstract}

Kata kunci: Internalisasi, Nilai-nilai, Pancasila

\section{PENDAHULUAN}

Kesemrawutan kondisi bangsa sebenarnya tidak lepas dari tanggung jawab dan peran pendidikan. Tujuan pendidikan bukan hanya membentuk warga negara yang cerdas dan terampil dalam pekerjaan, tetapi juga menghasilkan warga negara yang bermoral. Oleh karena itu pendidikan seyogyanya tidak semata-mata mentransfer ilmu pengetahuan kepada peserta didik, tetapi juga mentransfer nilai-nilai moral dan nilai-nilai kemanusiaan yang bersifat universal. Dan pendidikan merupakan tanggung jawab semua pihak, sekolah, keluarga dan masyarakat serta pemerintah.

Dengan transfer ilmu dan transfer moral yang bersifat universal, maka memunculkan harapan kepada peserta didik dapat menghargai kehidupan orang lain yang tercermin dalam tingkah laku dan aktualisasi diri, semenjak kecil hingga dewasa menjadi warga negara yang baik.

Para pendiri bangsa telah, mengamanatkan" bangunlah jiwanya, bangunlah badannya untuk Indonesia Raya“. Dari dasar itu betapa pentingnya pembangunan mental dalam hidup bernegara. Rusaknya alam negeri ini, menguapnya berbagai anggaran negara, hancurnya generasi muda oleh serangan Narkoba disebabkan oleh ulah orang yang pandai, sehat badannya namun jiwanya gersang dan miskin. Fakta inilah yang menjadi langkah awal untuk memperjuangkan kembali dalam menginternalisasikan nilai-nilai luhur bangsa demi membenahi dunia pendidikan dan mempersiapkan strategi bagaimana dapat melahirkan generasi yang cerdas dan bebas dari Narkoba.

Generasi yang cerdas dan bebas narkoba merupakan cita-cita bangsa dan negara yang bisa diwujudkan dengan internalisasi nilainilai pancasila. Pancasila bukanlah jargon kosong yang muncul ditengah-tengah masyarakat bangsa Indonesia, namun ia merupakan Core Values inklusif yang di gali oleh para pendiri bangsa yang mencoba mempertemukan nilai-nilai ideal yang mampu mewujudkan cita-cita Bhinneka Tunggal Ika.

Pancasila sebagaimana yang dirumuskan oleh penggalinya adalah pandangan hidup 
yang muncul dalam mengenali realitas sosio politik bangsa Indonesia. Pancasila adalah usaha bersama yang dilandasi semangat konsensus dari Founding Father. Pancasila adalah upaya dan muara yang paling mungkin disepakati dari beragamnya aspek plural kehidupan masyarakat Indonesia. Para pendiri bangsa ini telah mewariskan kepada kita suatu dasar falsafah bangsa dan pandagan hidup negara yang menjiwai penyusunan UUD 1945 yang begitu visoner dan tahan banting (durable). Suatu dasar falsafah yang memiliki landasan ontologis, epistemologis dan aksiologis yang kuat, yang jika di fahami secara mendalam, diyakini secara teguh, dan diamalkan secara konsisten dapat mendekati perwujudan negara paripurna.

\section{Konsepsi Pancasila}

Pancasila adalah ideologi dasar bagi negara Indonesia. Nama ini terdiri dari dua kata dari Sansekerta: Pañca berarti lima dan Ślla berarti prinsip atau asas. Pancasila merupakan rumusan dan pedoman kehidupan berbangsa dan bernegara bagi seluruh rakyat Indonesia. (Suwarno, P.J. 1991:12). Pancasila yang berarti lima dasar atau lima asas adalah nama dasar Negara kita, Negara Kesatuan Republik Indonesia. (Darji Dharmodiharjo. 1991 : 15 ). Sedangkan Dwiyanto dan Saksono (2012:93) mengungkapkan pancasila berfungsi sebagai idealisme maka tidakan yang kita lakukan merupakan digunakan sebagai prinsip yang regulatif dalam tatanan hidup berbangsa dan bernegara. Berikutnya Lima sendi utama penyusun Pancasila adalah Ketuhanan Yang Maha Esa, Kemanusiaan yang adil dan beradab, persatuan Indonesia, kerakyatan yang dipimpin oleh hikmat kebijaksanaan dalam permusyawaratan/perwakilan, dan keadilan sosial bagi seluruh rakyat Indonesia, dan tercantum pada paragraf ke-4 Preambule (Pembukaan) Undang-undang Dasar 1945.

\section{Nilai - Nilai Pancasila}

Pancasila merupakan dasar filsafat negara Indonesia, yang nilai-nilainya telah ada pada bangsa Indonesia sejak zaman dahulu kala, berupa nilai-nilai adat istiadat, kebudayaan dan nilai agama. dengan demikian sila Ketuhanan yang Maha Esa nilainya telah ada pada bangsa indonesia sebagai Kausa materialis.

Bila kita fahami nilai Ketuhanan Yang Maha Esa, maka terdapat nilai-nilai berupa :

a. Bangsa Indonesia menyatakan kepercayaannya dan ketakwaannya terhadap Tuhan Yang Maha Esa.

b. Manusia Indonesia percaya dan takwa terhadap Tuhan Yang Maha Esa, sesuai dengan agama dan kepercayaannya masing-masing menurut dasar kemanusiaan yang adil dan beradab.

c. Mengembangkan sikap hormat menghormati dan bekerjasama antara pemeluk agama dengan penganut kepercayaan yang berbeda-beda terhadap Tuhan Yang Maha Esa.

d. Membina kerukunan hidup di antara sesama umat beragama dan kepercayaan terhadap Tuhan Yang Maha Esa.

e. Agama dan kepercayaan terhadap Tuhan Yang Maha Esa adalah masalah yang menyangkut hubungan pribadi manusia dengan Tuhan Yang Maha Esa.

f. Mengembangkan sikap saling menghormati kebebasan menjalankan ibadah sesuai dengan agama dan kepercayaannya masing-masing.

g. Tidak memaksakan suatu agama dan kepercayaan terhadap Tuhan Yang Maha Esa kepada orang lain.

Berikutnya masuk kepada sila Kemanusiaan Yang Adil dan Beradab. Untuk memahami hakikat sila Kemanusiaan Yang Adil dan Beradab maka terlebih dahulu di bahas kedudukan manusia dalam negara. Kaelan (2013: 28) mengungkapkan berbagai pemikir besar tentang negara mendeskripsikan bahwa manusia dalam merealisasikan dan meningkatkan harkat dan martabatnya tidaklah mungkin untuk dipeuhinya sendiri, oleh karena itu manusia sebagai mahkluk sosial senantiasa membutuhkan orang lain dalam hidupnya.

Maka dari itu dalam hubungan ini pengertian negara sebagai suatu persekutuan hidup bersama dari masyarakat, adalah 
memiliki kekuasaan politik, mengatur hubungan-hubungan, kerjasama dalam masyarakat untuk mencapai tujuan tertentu yang hidup dalam suatu wilayah tertentu. Terkait dengan hal tersebut di atas, maka sila Kemanusiaan Yang Adil dan Beradab memiliki nilai-nilai sebagai berikut :

a. Mengakui dan memperlakukan manusia sesuai dengan harkat dan martabatnya sebagai makhluk Tuhan Yang Maha Esa.

b. Mengakui persamaan derajat, persamaan hak, dan kewajiban asasi setiap manusia, tanpa membeda-bedakan suku, keturunan, agama, kepercayaan, jenis kelamin, kedudukan sosial, warna kulit dan sebagainya.

c. Mengembangkan sikap saling mencintai sesama manusia.

d. Mengembangkan sikap saling tenggang rasa dan tepa selira.

e. Mengembangkan sikap tidak semenamena terhadap orang lain.

f. Menjunjung tinggi nilai-nilai kemanusiaan.

g. Gemar melakukan kegiatan kemanusiaan.

h. Berani membela kebenaran dan keadilan.

i. Bangsa Indonesia merasa dirinya sebagai bagian dari seluruh umat manusia.

j. Mengembangkan sikap hormat menghormati dan bekerjasama dengan bangsa lain.

Pancasila merupakan suatu nilai yang bersifat rohaniah, dan sebagai nilai merupakan prinsip yang sifatnya universal. maka struktur, sifat-sifat, keadaan, serta realitas negara harus senantiasa koheren dengan sila-sila Pancasila yaitu Tuhan, manusia, satu, rakyat dan adil. Maka sifat mutlak kesatuan bangsa, wilayah, dan susunan negara yang terkandung dalam sila Persatuan Indonesia harus koheren dengan hakikat satu. Berangkat dari itu maka sila Persatuan Indonesia memiliki nilai-nilai sebagai berikut :

a. Mampu menempatkan persatuan, kesatuan, serta kepentingan dan keselamatan bangsa dan negara sebagai kepentingan bersama di atas kepentingan pribadi dan golongan. b. Sanggup dan rela berkorban untuk kepentingan negara dan bangsa apabila diperlukan.

c. Mengembangkan rasa cinta kepada tanah air dan bangsa.

d. Mengembangkan rasa kebanggaan berkebangsaan dan bertanah air Indonesia.

e. Memelihara ketertiban dunia yang berdasarkan kemerdekaan, perdamaian abadi, dan keadilan sosial.

f. Mengembangkan persatuan Indonesia atas dasar Bhinneka Tunggal Ika.

g. Memajukan pergaulan demi persatuan dan kesatuan bangsa.

\section{Konsepsi Narkoba}

Narkotika merupakan bagian dari narkoba, yang berasal dari bahasa yunani "narke" yang berarti terbius dan tidak merasakan apa-apa (Sudarto, 1983: 36) kandungan zat yang ada di dalamnya menimbulkan efek tidak sadarkan diri terhadap segala perilaku yang ditampilkan oleh pengguna. Menurut ensiklopedia Amerika, pengertian narkoba adalah sebagai berikut :

"A drug that dulls the senses, relieves pain, iduces sleep, and can produce additction in wartying degres". "drug" diartikan sebagai "a chemical agent that is used therapeutically to treat disease . more groadly, a drug may be defined as any chemical agent attach living protoplasem".

Smith Kline dan French Staff dalam bukunya "Drug abuse amanual for law enforcement officer" definisi narkotika sebagai berikut :

"Narcontics are drug which produce insensibility or stupor due to their deperessant effect in the centrl vervous system. Included in this definition are opium, opium dervatives (morpine, codein, heroin) and synthetic apiates (meperidin, methadone). Artinya narkotika adalah zat-zat yang dapat mengakibatkan ketidaksadaran atau pembiusan disebabkan zat tersebut bekerja mempengaruhi susunan syaraf sentral. Dengan demikian narkotika ini sudah termasuk jenis candu, zat-zat 
yang dibuat dari candu (miopin dan lain-lain.)".

Definisi lain dari Biro Bea dan Cukai Amerika Serikat dalam bukunya "Narcotic identification manual" (1986: 12) mengatakan bahwa: "Narkotika adalah candu, ganja, cocaina, zat-zat yang berbahaya mentahnya diambil dari bendabenda tersebut yakni morpine, heroin, codein, dan termasuk juga narkotika sintesis yang menghasilkan zat-zat, petidine, dan methadone".

Di Indonesia penyalahgunaan narkoba diatur dalam Undang-Undang Nomor 35 Tahun 2009 tentang Narkotika. Dalam Undang-Undang ini dijelaskan bahwa yang dimaskud dengan narkotika adalah :

"Narkotika adalah zat atau obat yang berasal dari tanaman atau bukan tanaman, baik sintetis maupun semisintesis, yang dapat menyebabkan penurunan atau perubahan kesadaran, hilangnya rasa, mengurangi sampai menghilangkan rasa nyeri, dan dapat menimbulkan ketergantungan, yang dibedakan ke dalam golongangolongan sebagaimana terlampir dalam undang-undang ini".

Dari beberapa definisi di atas dapat disimpulkan bahwa zat-zat yang terkandung di dalam narkotik merupakan zat yang berbahaya jika dikonsumsi secara kontinyu dan menimbulkan reaksi tidak sadarkan diri atau mati rasa. Ada beberapa zat yang tergolong narkotika, yaitu ganja, heroin, kokain, morfin opium, pedited benzetidin, betametadol, kodein, dan turunannya. Narkotika dan narkoba pada dasarnya sama merupakan sekelompok zat yang umumnya mempunyai resiko yang dapat menimbulkan dampak buruk bagi para penggunanya. Ketergantungan terhadap narkoba akan berakibat gangguan fisik dan jiwa, karena terjadi kerusakan pada organ tubuh dan syaraf-syaraf pusat pada tubuh manusia.

\section{Data dan Fakta Penyalahgunaan Narkoba di Kalangan Pelajar di Indonesia}

Nilai-nilai Pancasila menjadi salah satu benteng pertahanan moral bangsa dalam menanggulangi serangan globalisasi diantaranya narkotika dan obat-obatan terlarang atau Narkoba. Narkoba menjadi musuh besar bagi dunia dan Indonesia, Indonesia menjadi salah satu yang menjadi sasaran para mafia atau kartel kejahatan Narkoba jaringan internasional.

Sejak lama bangsa Indonesia telah dilanda wabah nasional yang berpotensi merusak dan meruntuhkan ketahanan bangsa khususnya generasi muda atau pelajar yaitu penyalahgunaan dan peredaran gelap Narkoba, baik yang diseludupkan dari luar negeri maupun yang ditanam dan di produksi di dalam negeri. Masalah tersebut tidak henti-hentinya ditanggulangi mulai diberlakukannya Intruksi presiden Nomor 6 Tahun 1971 bahwa kejahatan narkotika termasuk salah satu kejahatan dalam kategori subversif yang mengancam eksistensi Bangsa" dan ditindaklanjuti dengan pembentukan Badan Koordinator pelaksana Inpres No 06/1972 (Bakolak Inpres).

Kemudian pemerintah menerbitkan UU nomor 9 tahun 1976 tentang Narkotika, UU Nomor 5 tahun 1997 tentang psikotropika dan UU nomor 22 tahun 1997 sebagai revisi UU nomor 9/1976. Namun ,masalah narkotika terus merajalela yang menjadikan negara Indonesia sebagai tidak hanya sebagai transit Narkoba tapi juga sebagai produsen Narkoba.

Penyalahgunaan narkoba sebagaimana dikemukakan sebelumnya memiliki dampak sistemik terhadap rusaknya jaringan-jaringan dalam tubuh, terutama jaringan otak. Dampak penyalahgunaan narkoba dapat merugikan diri sendiri, masyarakat, dan lingkungan sekitar. Secara fisik narkotika dapat merusak tubuh si pemakai, diantaranya kerusakan otot jantung, ketidakteraturan denyut jantung dan pembengkakan hati. Begitu pula dengan pemakai yang memakainya dengan cara suntik dapat mengakibatkan keracunan pada darah dan pembengkakan hati.

Selain secara fisik tidak sehat, mentalpun ikut terganggu yaitu dengan rusaknya akal. Bagi mereka yang sudah mengalami ketergantungan bila pemakai 
dihentikan akan menimbulkan sindrom putus alkohol (sakau), seperti mual dan muntahmuntah, jantung berdebar, keringat berlebihan, tekanan darah tinggi, gelisah, tidak tenang, dan munculnya rasa takut, perubahan perasaan mudah tersinggung atau murung, tekanan darah menurun karena perubahan posisi duduk, dan halusinasi dengar (mendengar suara-suara tertentu padahal suara tersebut tidak ada).

Penggunaan narkoba juga memiliki dampak bagi lingkungan sosial. Akibat dari penyalahgunaan narkotika di bidang sosial ini biasanya terjadi secara bertahap, diawali dengan mulai membantah orang tua, meninggalkan ibadah, bolos sekolah, prestasi semakin menurun, mulai suka berbohong, terlibat pencurian, atau tindak criminal lainnya, timbulnya sikap yang agresif dan berbagai perbuatan yang meresahkan lingkungan sekitarnya.

Sebagai upaya meneguhkan semangat bahwa Narkotika merupakan musuh bersama bangsa, maka Presiden RI menerbitkan Inpres nomor 3 tahun 2002 tentang upaya pencegahan dan pemberantasan penyalahgunaan dan peredaran Narkoba sebagai upaya yang komprehensif dalam mengurangi permintaan dan sediaan Narkoba (demand and suply eductioan). Adapun kerawanan Narkoba di Indonesia dapat di lihat dari beberapa indikator (BNN : 2012) diantaranya adalah:
1. Banyaknya kasus menonjol dengan barang bukti yang bernilai (omzet) milyaran rupiah.

2. Banyak tersangka Narkoba baik WNA maupun WNI yang tertangkap karena Narkoba.

3. Kurir dan jarigan Narkoba yang semakin massif dan terstruktur.

4. Pelaku dan jaringan baru sindikat Narkoba.

5. Modus - modus operandi Narkoba yang semakin bervariasi.

6. Jalur-jalur baru penyelundupan dan perdagangan gelap Narkoba.

7. Jenis dan ragam barang bukti Narkoba.

Berdasarkan data kejahatan Narkoba di

Indonesia periode 2007-2011 (BNN : Maret 2012), teridentifikasi bahwa :

Jumlah tersangka kejahatan pada usia usia pelajar dan mahasiswa (12-24 tahun) sebesar 40.690 orang $(21,5 \%$ dari total tersangka Narkoba). Sedang dari aktifitas sebagai Pelajar dan Mahasiswa saat ditangkap sebagai pelaku kejahatan Narkoba sebesar 6.280 orang $(3,4 \%)$. Sementara dari segi pendidikan terakhir, umumnya tersangka Narkoba berpendidikan SMA $(61,9 \%)$, SMP $(23,7 \%)$, SD $(11,8 \%)$, dan PT $(2,6 \%)$.

Data identifikasi kejahatan narkoba di Indonesia tahun 2007-2011 di atas akan disajikan ke dalam bentuk tabel sebagai berikut :

Tabel 1. Identifikasi kejahatan narkoba kategori pelajar/mahasiswa di Indonesia

Tahun 2007-2011

\begin{tabular}{|c|l|l|l|}
\hline No. & \multicolumn{1}{|c|}{ Kategori } & \multicolumn{1}{c|}{ Jumlah } & \multicolumn{1}{c|}{ Presentase } \\
\hline 1 & $\begin{array}{l}\text { Tersangka Kejahatan pada usia Pelajar dan } \\
\text { Mahasiswa (12-24 Usia) }\end{array}$ & 40.690 & $21,5 \%$ \\
\hline 2 & Aktifitas Sebagai Pelajar & 6.280 & $3,4 \%$ \\
\hline
\end{tabular}

Sumber : BNN 2012

Tabel. 2 Identifikasi kejahatan narkoba kategori jenjang pendididkan di Indonesia Tahun 2007-2011

\begin{tabular}{|r|l|l|}
\hline \multicolumn{1}{|c|}{ No. } & Jenjang Pendidikan & Presentase \\
\hline 1 & Sekolah Menengah Atas (SMA) & $61,9 \%$ \\
\hline 2 & Sekolah Menengah Pertama (SMP) & $23,7 \%$ \\
\hline 3 & Sekolah Dasar (SD) & $11,8 \%$ \\
\hline 4 & Perguruan Tinggi (PT) & $2,6 \%$ \\
\hline Total & & $100 \%$ \\
\hline
\end{tabular}

Sumber : BNN 2012 
Data dan fakta diatas terlihat bahwa 21,5\% kejahatan Narkoba dilakukan oleh pelaku yang seharusnya masih berusia belajar di sekolah dan kuliah (12-24 tahun). Pada usia antara 12-24 tahun seharusnya seorang anak didik belajar dan mengembangkan diri tetapi ditangkap karena kasus Narkoba. Narkoba akan menimbulkan masalah psikis dan stigmatisasi masyarakat di masa depan, karena status menjadi tersangka, di dakwa sebagai penjahat, dikenal sebagai mantan warga negara binaan atau bekas residen yang selesai dirawat. Hal tersebut tentu sedikit banyak mengganggu kelangsungan hidupnya bila kelak dia kembali ke masyarakat.

Bertolak dari fakta bahwa mayoritas penjahat kasus Narkoba berpendidikan terakhir SMA, maka potensi rawan remaja yang lulus SMA atau putus sekolah atau kuliah menjadi paling tinggi. Bila kemauan dan kemampuannya beradaptasi dalam masyarakat tidak seimbang akibat gaya hidup dan pergaulan yang salah maka lulusan SMA yang tidak memiliki aktifitas positif bagai api dalam sekam yang bila tidak diawasi akan menjadi pelaku baru Narkoba, baik pengguna illegal maupun pengedar gelap.

Sebagaimana data yang telah dipaparkan di atas, kawasan perkotaan cenderung memiliki tingkat kerawanan Narkoba yang lebih tinggi di banding dengan daerah pedesaan. Pada hasil survei nasional penyalahgunaan Narkoba pada rumah tangga dan rumah kost oleh BNN dan UI (2010), terbukti bahwa angka prevalensi setahun terakhir masyarakat kota $(0,7 \%)$ dan masyarakat desa (0,4\%). Pada angka prevalensi pernah pakai, masyarakat kota sebesar $2,7 \%$ dan masyarakat desa sebesar $1,5 \%$.

Tabel. 3 Penyalahgunaan Narkoba pada Rumah Tangga dan Rumah Kost

\begin{tabular}{|l|l|l|l|}
\hline No. & Kategori & Masyaraka Kota & Mayarakat Desa \\
\hline 1 & Prevalensi & $0,7 \%$ & $0,4 \%$ \\
\hline 2 & Prevalensi Pernah Pakai & 2,7 & 1,5 \\
\hline
\end{tabular}

Narkoba yang memiliki berbagai jenis dan bentuk mampu mengelabui pemikiran pelajar Indonesia baik yang secara sengaja maupun terperangkap pada jebakan-jebakan para pengedar Narkoba. Dalam UndangUndang Nomor 35 tahun 2009 tentang Narkotika pasal 1 ayat 1 menjelaskan bahwa:

"Narkotika adalah zat atau obat yang berasal dari tanaman atau bukan tanaman, baik sintetis maupun semisintetis,yang dapat menyebabkan penurunan atau perubahan kesadaran, hilangnya rasa, mengurangi sampai menghilangkan rasa nyeri, dan dapat menimbulkan ketergantungan, yang dibedakan ke dalam golongan golongan sebagaimana terlampir dalam Undang-Undang ini."

Kemudian dalam Undang-Undang yang sama dijelaskan tentang tujuan dari Undang tersebut di buat, sesuai dengan yang tertera pada bab II pasal 4 yaitu :

Undang-Undang tentang Narkotika bertujuan:
1. Menjamin ketersediaan Narkotika untuk kepentingan pelayanan kesehatan dan/atau pengembangan ilmu pengetahuan dan teknologi;

2. Mencegah, melindungi, dan menyelamatkan bangsa Indonesia dari penyalahgunaan Narkotika;

3. Memberantas peredaran gelap Narkotika dan Prekursor Narkotika; dan

4. Menjamin pengaturan upaya rehabilitasi medis dan sosial bagi Penyalah guna dan pecandu Narkotika

Berangkat dari penjelasan di atas dan melihat fenomena beberapa tahun belakangan ini kita dapat menilai betapa bahaya dan massifnya serangan Narkoba bagi genarasi muda. Tidak terkecuali para peserta didik atau generasi emas pelajar Indonesia. Pelajar yang merupakan aset berharga bagi bangsa sebagai generasi penerus mendapat tantangan yang besar dalam menghadapi era globalisasi yang serba terbuka dan tanpa batas pergaulan baik secara langsung maupun secara tidak langsung. 
Pelajar atau remaja atau siswa memiliki makna sebagaimana yang di sebutkan dalam kamus besar bahasa Indonesia yaitu :

Siswa/ siswi merupakan istilah bagi peserta didik pada jenjang pendidikan dasar dan menengah. Siswa atau peserta didik adalah mereka yang secara khusus diserahkan oleh kedua orang tuanya untuk mengikuti pembelajaran yang diselenggarakan di sekolah, dengan tujuan untuk menjadi manusia yang berilmu pengetahuan, berketerampilan, berpengalaman, berkepribadian, dan mandiri.

Sedangkan dalam Undang-Undang nomor 20 tahun 2003 tentang Sistem Pendidikan Nasional pasal 1 ayat 4 menyebutkan bahwa peserta didik adalah anggota masyarakat yang berusaha mengembangkan potensi diri melalui proses pembelajaran yang tersedia pada jalur, jenjang, dan jenis pendidikan tertentu. Sedangkan menurut WHO dalam BNN (45:2012) mengatakan bahwa:

Remaja atau pelajar didefinisikan sebagai masa peralihan dari masa kanak-kanak ke masa dewasa, sedangkan batasan usia remaja adalah 12 - 24 tahun. Namun jika pada masa remaja sudah menikah maka tergolong dalam masa remaja. Sedangkan dalam ilmu psikologi rentang usia remaja dibagi menjadi tiga yaitu remaja awal (10-13 tahun), remaja pertengahan (1416 tahun), remaja akhir (17-19 tahun).

Maka semakin jelas bahwa pelajar menjadi ujung tombak yang akan meneruskan cita-cita dan perjuangan bangsa Indonesia, namun Narkoba menjadi musuh besar dari tumbuh kembangnya pemikiran dan pendewasaan para pelajar Indonesia. Oleh karena itu perlu dilakukan langkah langkah untuk mengantisipasi atau langkah pencegahan dari serangan Narkoba. Hal tersebut dapat dilakukan dengan internalisasi nila-nilai Pancasila bagi pelajar Indonesia.

Saat ini penyalahgunaan narkoba banyak dilakukan oleh kalangan pelajar, terutama dalam rentang usia 12-16 tahun (usia SMP). Penyalahgunaan narkoba di kalangan pelajar termasuk dalam kategori kenakalan pelajar (juvenile deliquences). Kenakalan pelajar muncul sebagai akibat adanya ketidaktahuan terhadap nilai-nilai yang berlaku pada masyarakat. Menurut Hurlock dalam Willis (2010:89) kerusakan moral pada pelajar dapat disebabkan oleh beberapa hal sebagai berikut:

a. Keluarga yang sibuk, keluarga retak, keluarga single parent dimana anak hanya diasuh oleh ibu

b. Kewibawaan sekolah dalam mengawasi anak

c. Peranan lembaga yang tidak mampu menangani masalah moral.

Beberapa faktor sebagaimana dikemukakan diatas, membuat pelajar mencari kehidupan di luar lingkungan keluarga dimana lingkungan pergaulan pelajar merupakan salah satu faktor utama terjadinya kerusakan moral pada pelajar. Lingkungan keluarga tidak nyaman dapat membuat anak melakukan suatu kenakalan untuk mencapai perhatian. Disertai kurangnya pemahaman pelajar tentang agama menjadi faktor utama kerusakan moral.

Walaupun tidak semua remaja atau pelajar di Indonesia menyalahgunakan Narkoba sudah menjadi gambaran umum bahwa kelompok yang paling banyak terlibat dalam masalah Narkoba adalah remaja atau pelajar. Ada beberapa ciri perkembangan remaja yang rentan terhadap permasalahan penyalahgunaan Narkoba seperti yang diutarakan oleh Badan Narkotika Nasional yaitu sebagai berikut : (a) perasaan galau, (b) perasaan ingin tahu, (c) kegoncangan emosional, (d) cenderung melawan otoritas.

(e) tekanan kelompok sebaya.

Berikut beberapa data yang dapat di lihat dari hasil pencegahan dan penindakan yang dilakukan oleh Badan Narkotika Nasional Kota Pontianak diantaranya :

Dari hasil survei tahun 2011 menunjukkan dari 100 orang pelajar/ mahasiswa terdapat 4 orang pernah menyalahgunakan Narkoba , 3 orang menyalahgunakan dalam setahun terakhir, dan 2-3 orang dalam sebulan terakhir. Angka tersebut lebih rendah 
dibanding pada dua survei sebelumnya, yaitu sekitar 8 orang pernah pakai dan 5 orang pernah menyalahgunakan dalam setahun terakhir dan dilanjutkan dengan Berikut secara berurutan adalah angka penyalahgunaan Narkoba tahun survei 2006, 2009 dan 2011. Angka coba pakai $(7.3 \%, 3.7 \%$ dan $1.9 \%)$, teratur pakai $(4.8 \%, 1.1 \%$ dan $0.8 \%)$, pecandu bukan suntik $(1.2 \%, 0.2 \%$ dan $0.4 \%)$, pecandu suntik $(0.3 \%, 0.1 \%$ dan $0.3 \%$ ). Dan penjelasan mengenai Umur pertama kali pelajar/ mahasiswa menyalahgunakan Narkoba sangat bervariasi antara berbagai jenjang sekolah. Hasil survei tahun 2009 dan 2011 menunjukkan umur pertama kali menyalahgunakan Narkoba pada median 16 tahun, sedangkan survei tahun 2006 pada median 12 tahun. Dari ketiga hasil survei menunjukkan pola yang sama yaitu semakin rendah jenjang sekolah semakin muda umur responden pertama kali mulai menyalahgunakan Narkoba.

Angka penyalahgunaan Narkoba periode tahun 2006, 2009 dan 2011 berikut akan dipaparkan ke dalam tabel 4.

Tabel. 4 Penyalahgunaan Narkoba periode tahun 2006, 2009 dan 2011

\begin{tabular}{|r|l|l|l|l|}
\hline No. & Kategori & $\mathbf{2 0 0 6}$ & $\mathbf{2 0 0 9}$ & $\mathbf{2 0 1 1}$ \\
\hline 1 & Coba Pakai & $7,3 \%$ & $3,7 \%$ & $1,9 \%$ \\
\hline 2 & Teratur Pakai & $4,8 \%$ & $1,1 \%$ & $0,8 \%$ \\
\hline 3 & Pecandu bukan suntik & $1,2 \%$ & $0,2 \%$ & $0,4 \%$ \\
\hline
\end{tabular}

Sumber : BNN 2012

Data di atas menunjukkan betapa rentannya pelajar terhadap bahaya Narkoba, untuk itulah selain upaya yang terus menerus penanaman nilai-nilai Pancasila di lingkungan pelajar dengan pengembangan konsep dan metodologi juga tidak kalah pentingnya dengan Internalisasi nilai-nilai Pancasila di lingkungan masyarakat (community civics) dalam rangka mencegah semakin banyaknya korban-korban narkoba terutama para pelajar yang menjadi geneasi emas bangsa dan negara Indonesia.

\section{Internalisasi Nilai-Nilai Pancasila Sebagai Upaya Menanggulangi Penyalahgunaan Narkoba}

Realisasi nilai-nilai Pancasila dasar filsafat bangsa Indonesia, perlu secara berangsur-angsur dengan jalan pendidikan baik di sekolah maupun dalam masyarakat dan keluarga sehingga dapat mewujudkan cita-cita bangsa dan negara. Internalisai nilainila Pancasila dapat dijelaskan dan dijabarkan sebagai berikut seperti yang diungkapkan oleh Kaelan ( 2013:685) :

Dengan Internalisasi nilai-nilai Pancasila maka akan diperoleh hal-hal sebagai berikut : a. Pengetahuan : suatu pengetahuan yang benar tentang Pancasila baik aspek nilai, norma, maupun aspek praksisnya. hal ini harus disesuaikan dengan tingkat pengetahuan dan kemampuan individu. Bagi kalangan intelektual pengetahuan itu meliputi aktualisasi pengetahuan biasa (sehari-hari), pengetahuan ilmiah, dan pengetahuan filsafat tentang Pancasila. Hal ini sangat penting terutama bagi calon pemimpin bangsa dan calon ilmuwan. Dalam proses transformasi pengetahuan ini diperlukan waktu yang cukup lama dan berkesinambungan, sehingga pengetahuan itu benar-benar dapat tertanam dalam setiap individu. Tanpa pendidikan yang cukup maka dapat dipastikan bahwa pemahaman tentang ideologi bangsa dan dasar filsafat negara hanya dalam tingkat pragmatis, dan hal ini sangat berbahaya bagi terhadap ketahan ideologi generasi penerus bangsa.

b. Keadaran : selalu mengetahui pertumbuhan keadaan yang ada dalam diri sendiri.

c. Ketaatan : selalu dalam keadaan kesediaan untuk memenuhi wajib lahir dan bathin, lahir berasal dari luar misalnya pemerintah, adapun bathin dari diri sendiri. 
d. Kemampuan kehendak: cukup kuat sebagai pendorong untuk melakukan perbuatan.

e. Watak dan hati nurani : agar orang selalu mawas diri, yaitu : 1) Dengan menilai diri sendiri apakah dirinya berbuat baik atau buruk dalam melaksanakan Pancasila dan memberi sanksi bathin yang bersifat pujian atau celaan kepada diri sendiri, atau sebelum melakukan perbuatan membuat pedoman pancasila. Adapun pedoman tersebut bisa berupa perintah, larangan, anjuran, atau membiarkan untuk berbuat / tidak berbuat yang ditaatinya sendiri. apabila tidak mentaati akan diberikan sanksi bathin berupa celaan terhadap diri sendiri; 2) Apabila telah melaksanakan maka akan diperoleh suatu kesiapan pribadi untuk mengaktualisasikan pancasila, yang selanjutnya akan merupakan suatu keyakinan tentang kebenaran; 3) Dengan demikian akan memiliki suatu ketahanan ideologi yang berdasarkan keyakinan atas kebnaran pancasila, sehingga dirinya akan merupakan sumber kemampuan, untuk memelihara, mengembangkan, mengamalkan, mewariskan, merealisasikan Pancasiladalam segala aspek kehidupan; 4) Jika setiap orang Indonesia telah memiliki kondisi yang demikian keadaannya maka setiap orang Indonesia akan berkepribadian berwatak dan berhati nurani Pancasila sehingga akan terjelmalah negara dan masyarakat Pancasila.

Pancasila telah ada dalan segala aspek kehidupan rakyat Indonesia terkecuali bagi mereka yang tidak Pancasilais. Pancasila lahir pada 1 Juni 1945 dan ditetapkan pada tanggal 18 Agustus 1945 bersama-sama dengan UUD 1945. bunyi dan ucapan pancasila yang benar bersasaskan inpres Nomor 12 tahun 1968 adalah

a. Ketuhan Yang Maha Esa

b. Kemanusiaan yang adil dan beradab

c. Persatuan Indonesia

d. Kerakyatan yang dipimpin oleh hikmat kebijaksanaan dalam permusyawaratan /perwakilan e. Keadilan sosial bagi seluruh rakyat Indonesia

Darji Dharmodiharjo (1998:45) mengungkapkan bahwa:

Sejarah telah mencatat kemerdekaan Indonesia di perjuankan oleh dua golongan, golongan tua dan golongan muda, yang golongan tua bertugas sebagai perencana kemerdekaan RI dan merumuskan Pancasila sedangkan golongan muda berfungsi sebagai penyemangat atau pendorong golongan tua agar NKRI cepat merdeka dan dasar Negara cepat dibentuk. Adapun golongan tua yang merumuskan dasar Negara yaitu MR. M. Yamin, Prof Soepomo, dan Ir. Soekarno.

Dapat dikemukakan mengapa Pancasila itu sakti dan selalu dapat bertahan dari guncangan kisruh politik di Negara ini, adapun alasannya sabagai berikut :

a. Karena secara intrinsik dalam Pancasila itu mengandung toleransi, dan siapa yang menantang Pancasila berarti dia menantang toleransi.

b. Pancasila merupakan nilai yang cukup Fleksibel, yang dapat mencangkup fahamfaham yang dianut oleh bangsa Indonesia, dan faham lain yang positif tersebut mempunyai keluluasaan yang cukup untuk memperkembangkan diri.

c. Karena sila-sila dalam Pancasila itu terdiri dari nilai-nilai dan norma-norma yang positif sesuai dengan pandangan hidup bangsa Indonesia

d. Karena bangsa Indonesia yang sejati sangat cinta kepada Pancasila, yakni bahwa Pancasila itu benar dan tidak bertentangan dengan keyakinan serta agamanya.

Berdasarkan beberapa pengertian diatas maka Sofyan Aman dkk (1982:10):

Dengan demikian Pancasila sebagai dasar Negara Indonesia yang harus diketahui oleh seluruh warga Negara Indonesia, agar menghormati, menghargai, menjaga dan menjalankan apaapa yang telah dilakukan oleh para pahlawan khususnya pahlawan proklamasi yang telah berjuang untuk 
kemerdekaan Negara Indonesia. Sehingga baik golongan muda dan tua tetap meyakini Pancasila sebagai dasar Negara Indonesia tanpa adanya keraguan guna memperkuat persatuan dan kesatuan bangsa dan Negara Indonesia.

Maka dari pada itu suatu keharusan bagi seluruh rakyat Indonesia agar dapat mengetahui Pancasila agar dapat memahami dan mengamalkan Pancasila dalam kehidupan sahari-hari. Maka dari pada itu kita harus mengetahui dan mengimplementasikan nilai-nilai Pancasila terkandung didalamnya.

Sebuah sewiping yang dilakukan oleh sebuah organisasi pemuda Pancasila di jember menyatakan pada saat sewiping banyak masyarakat yang tidak tau isi teks Pancasila tetapi mengInternalisasikan salah satu nilai-nilai Pancasila. (Koran jember : Edisi IV : 11

Seminar yang dihadiri kurang lebih 100 peserta dari Surabaya, Magetan, Pasuruan, Tuban, Lamongan, Gresik dan beberapa kota di Jawa Timur, sebagian besar adalah pendidik dari berbagai tingkatan sekolah. Hal ini penting sebagai pendidik generasi penerus bangsa. Seminar yang diadakan karena keprihatinan atas krisis Internalisasi nilai-nilai Pancasila dalam kehidupan berbangsa dan bernegara. "Ikatan berbangsa sebagai bangsa retak. Pancasila tidak lagi sebagai acuan dalam berbangsa. Perbedaan cultural menjadi pemicu. Pengaruh asing, liberalisme dan kapitalisme makin memicu keadaan tersebut." Aruchat Jaswadi, ketua CSIS dalam sambutannya.

Sebagai keynote speaker dalam acara tersebut, Kombes Widiyanto, direktur penanganan konflik dari kesbang, hadir mewakili dirjen kesbang. Dalam sambutannya menyatakan pada saat ini Pancasila seakan memudar dari kehidupan bangsa Indonesia. Realita pada tatanan sosial dengan maraknya konflik mementingkan kepentingan kelompok atau pribadi menyampingkan kepentingan berbangsa. "Kehidupan masyarakat yang ber-Pancasila, dirasakan mulai memudar. Makin maraknya konflik dan tindakan-tidakan anarkis. Disebabkan kepen- tingan kelompok menyampingkan kepentingan bangsa. Jangan dibiarkan berlarutlarut, diatasi dengan melakukan usaha-usaha seperti mengadakan seminar."

Nada serupa juga disampaikan oleh $\mathrm{H}$. Soekarwo, gubernur Jawa Timur dalam sambutannya diwakili oleh asisten III, Akmal Budianto "Mulai bergesernya nilai-nilai Pancasila dalam kehidupan sehari-hari. Egoisme dan kesukuan semakin kental. Aspek nasional sebagai ketahanan spiritual merupakan nilai-nilai Pancasila dalam berbangsa, Keprihatinan mengabaikan nilainilai Pancasila dalam kehidupan berbangsa dan bernegara. “

Dari semua pembicara dapat disimpulkan bahwa Pancasila tetap merupakan ideologi nasional. Dimana pada masa awal reformasi pruralisme yang terjadi dibiarkan berkembang tanpa adanya kontrol dari Pancasila. Hingga terjadilah konflik dalam berbangsa dan bernegara.

Maka pada saat ini Pancasila dihidupkan kembali sebagai dasar dari nilai pluralisme dan sebagai dasar dari pembentukan pribadi bangsa. Proses Internalisasi Pancasila harus diikuti dengan strategi dan metode yang relevan dan memadai. Hal ini berdasarkan realitas objektif, bahwa subjek dan objek internalisai dan aktualisasi adalah manusia dan dalam lingkungan masyarakat, bangsa dan negara. Proses internalisasi dan aktualisasi pancasila harus diterapkan denga metode yang efektif. salah satu metode efektif tersebut adalah melalui lingkungan pendidikan, baik formal, informal maupun non formal. Internalisasi dilakukan dan dijelaskan dalam berbagai konteks lingkungan tersebut tetapi tetap memperhatikan lingkungan sosial masyrakat, pengetahuan masyarakat, serta karakteristik masyarakat.

\section{PENUTUP}

Internalisasi nilai-nilai Pancasila di kalangan pelajar merupakan langkah strategis untuk membentuk pelajar antinarkoba. Upaya internalisasi Pancasila memerlukan strategi dan metode yang relevan dan memadai. Dalam lingkungan pendidikan proses internalisasi ini dapat dilakukan melalui 
proses pembelajaran maupun berbagai organisasi di lingkungan sekolah. Melalui pembudayaan berbagai aktivitas di lingkungan sekolah nilai-nilai Pancasila dapat diinternalisasikan dengan terarah dan sistematis.

Upaya internalisasi ini merupakan langkah yang memerlukan kesatuan langkah dari setiap elemen masyarakat, baik keluarga, sekolah, pemerintah, maupun masyarakat secara keseluruhan. Keluarga yang merupakan lembaga sosialisasi primer bagi anak tentunya menjadi peletak dasar nilainilai Pancasila pada diri anak. Sekolah sebagai lembaga formal yang efektif dalam mentrasformasikan nilai-nilai Pancasila melalui sistem pendidikan. Pemerintah sebagai organ yang memiliki legalitas penuh dalam menerapkan berbagai regulasi untuk mengatur kehidupan masyarakat. Adapun masyarakat sebagai lingkungan keseharian para pelajar, yang setiap harinya banyak dipengaruhi oleh sistem sosial masyarakat. Dengan demikian, kerjasama diantara keseluruhan elemen tersebut sangat penting untuk menginternalisasikan nilai-nilai Pancasila di kalangan pelajar.

\section{DAFTAR PUSTAKA}

BNK Kota Pontianak (2012),. Data Penyalahgunaan Narkoba di Kota Pontianak Tahun 2012.
BNK Kota Pontianak (2012),. Pencegahan Penyalagunaan Narkoba Bagi Remaja. Pontianak : BNN.

BNN dan Puslitkes UI (2009),. Survei Perkembangan Penyalahgunaan dan Peredaran Gelap Narkoba pada Kelompok Pelajar di Indonesia. Jakarta: BNN

BNN Republk Indonesia (2012),. Rencana Aki Nasional Perberdayaan Masyarakat 2011-2015. Jakarta : BNN

Budimansyah, Dasim \& Bestari, Prayoga (2011) Aktualisasi Nilai - Nilai Pancasila dalam Membangun Karakter Warga Negara. Bandung : Widya Aksara Press

Jimly Assiddiqie dalam Kongres Pancasila Ketiga di Surabaya : No Publisher

Kaelan, (2013). Negara Kebangsaan Pancasila, Yogaykarta : Paradigma

Undang-Undang Dasar 1945 Republik Indonesia

Undang-Undang Republik Indonesia No 20 Tahun 2003 Tentang Sistem Pendidikan Nasional. Bandung : Citra Umbara.

Undang-Undang Republik Indonesia Nomor 35 Tahun 2009 tentang Narkotika

Undang-Undang Republik Indonesia Nomor 5 Tahun 1997 tentang Psikotropika

Undang-Undang Republik Indonesia Nomor 9 Tahun 1976 tentang Narkotika 